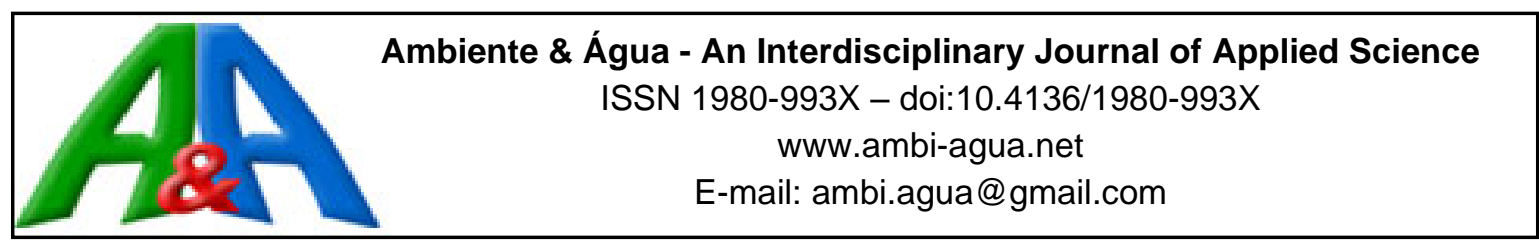

\title{
Effect of turbidity on ultraviolet disinfection of domestic wastewater for agricultural reuse
}

\author{
ARTICLES doi:10.4136/ambi-agua.2766
}

Received: 05 Jul. 2021; Accepted: 10 Nov. 2021

\section{Diego Fernando Atoche Garay ${ }^{10}$; Lisiana Crivelenti Voltolini ${ }^{\circledR D}$; Reinaldo Gaspar Bastos ${ }^{3}$; Claudinei Fonseca Souza ${ }^{1 * i 0}$}

\author{
${ }^{1}$ Centro de Ciências Agrárias. Departamento de Recursos Naturais e Proteção Ambiental. Universidade Federal \\ de São Carlos (UFSCar), Via Anhanguera, km 174, CEP: 13600-970, Araras, SP, Brazil. \\ E-mail: diegosatoche@hotmail.com \\ ${ }^{2}$ Centro de Ciências Agrárias. Programa de Pós-Graduação em Agricultura e Ambiente. Universidade Federal de \\ São Carlos (UFSCar), Via Anhanguera, km 174, CEP: 13600-970, Araras, SP, Brazil. \\ E-mail: lisianacrivelenti@yahoo.com.br \\ ${ }^{3}$ Centro de Ciências Agrárias. Departamento de Tecnologia Agroindustrial e Socioeconomia Rural. \\ Universidade Federal de São Carlos (UFSCar), Via Anhanguera, km 174, CEP: 13600-970, Araras, SP, Brazil. \\ E-mail: reinaldo.bastos@ufscar.br \\ *Corresponding author. E-mail: cfsouza@ufscar.br
}

\begin{abstract}
Water treatment and reuse are fundamental because of the increasing demand for freshwater, especially in agriculture. Accordingly, this study evaluated the effects of turbidity of wastewater processed at the Effluent Treatment Station (ETE) of the UFSCar/Araras and of UV dose on microbial inactivation. The ETE treats up to $2000 \mathrm{~L}$ of wastewater daily from toilets and a university restaurant and has five components (grease box, septic tank, microalgae tank, upflow anaerobic filter, and wetlands). Pretreated effluents were used in the experiments, and sampling sites consisted of inspection boxes located after the wetlands. Sample collection, inspection, preservation, and analyses were performed according to standard methods. Sample turbidity was adjusted to 5, 50, 100, 200, and 300 nephelometric turbidity units (NTU), and UV doses of 7.2-28.8 $\mathrm{mWs} \mathrm{cm}^{-2}$ were used. A 5 x 5 factorial design (five turbidity levels and five radiation doses) was used, totaling 25 treatments. Each treatment was performed in triplicate. The data were submitted to analysis of variance and Tukey's test. The results showed that the increase in turbidity significantly decreased disinfection efficiency in samples with turbidity levels higher than 50 NTU. The microbial inactivation coefficients obtained here can be extrapolated to disinfection of wastewater with turbidity up to 300 NTU to eliminate thermotolerant coliforms. The UV sterilizer is feasible for wastewater treatment and its reuse in agriculture.
\end{abstract}

Keywords: domestic effluent, sustainability, ultraviolet radiation, water reuse.

\section{Efeito da turbidez na desinfecção ultravioleta de águas residuais domésticas para reutilização agrícola}

\section{RESUMO}

O tratamento e o reúso da água são fundamentais devido à crescente demanda por água doce, principalmente na agricultura. Nesse sentido, este estudo teve como objetivo avaliar os 
efeitos da turbidez de águas residuárias tratada na Estação de Tratamento de Efluentes (ETE) da UFSCar/Araras e da dose de UV na inativação microbiana. A ETE trata até 2.000 litros de águas residuais diariamente de banheiros e um restaurante universitário e tem cinco componentes (caixa de graxa, fossa séptica, tanque de microalgas, filtro anaeróbio de fluxo ascendente e wetlands). Efluentes pré-tratados foram usados nos experimentos, e os locais de amostragem consistiram em caixas de inspeção localizadas após os wetlands. A coleta de amostras, inspeção, preservação e análises foram realizadas de acordo com métodos padrão. A turbidez da amostra foi ajustada para 5, 50,100, 200 e 300 unidades de turbidez nefelométrica (NTU) e doses de UV de 7,2-28,8 $\mathrm{mWs}^{-2}$ foram usadas. Foi utilizado um planejamento fatorial 5 x 5 (cinco níveis de turbidez e cinco doses de radiação), totalizando 25 tratamentos. Cada tratamento foi realizado em triplicata. Os dados foram submetidos à análise de variância e teste de Tukey. Os resultados mostraram que o aumento da turbidez diminuiu significativamente a eficiência da desinfecção em amostras com níveis de turbidez superiores a 50 NTU. Os coeficientes de inativação microbiana aqui obtidos podem ser extrapolados para a desinfecção de águas residuais com turbidez de até 300 NTU para eliminar coliformes termotolerantes. O esterilizador UV é viável para o tratamento de efluentes e sua reutilização na agricultura.

Palavras-chave: efluente doméstico, radiação ultravioleta, reúso de água, sustentabilidade.

\section{INTRODUCTION}

Increases in world population, urbanization, and water use for irrigation have led to irregular and disordered water supply, hence limiting water availability. This has promoted indirect reuse of wastewater without prior planning or treatment (Oliveira et al., 2019). However, after proper treatments, the reuse of effluents is an alternative to meet water demands of the agricultural sector, in which large amounts of freshwater are used (Zewde et al., 2019). Disinfection is considered a tertiary treatment, with emphasis on chlorination, ozonation, reverse osmosis, membrane filtration, and ultraviolet (UV) radiation (Collivignarelli et al., 2018). However, these treatments are expensive and increase the toxicity of effluents (Chai $e t$ al., 2018).

The purpose of UV sterilization is eliminating or inactivating microorganisms such as bacteria and viruses (Chhetri et al., 2018). UV radiation has been increasingly used in wastewater treatment in the last 25 years because of little contact time and high antimicrobial activity (Masschelein et al., 1989; Guo et al., 2009; Zewde et al., 2019).

UV disinfection of water and wastewater normally uses low-pressure mercury lamps at the $254 \mathrm{~nm}$ wavelength (Zewde et al., 2019). Short UV radiation (100 - $280 \mathrm{~nm}$ ) causes changes in DNA and RNA molecules, which absorb radiation at wavelengths between 200 and $300 \mathrm{~nm}$, especially at about $260 \mathrm{~nm}$. This radiation range alters the structure and function of nucleic acids, inhibiting DNA replication and inactivating microbial cells (Gibson et al., 2017). More recently, Silva et al. (2020) evaluated the inactivation of Escherichia coli in effluent from an urban wastewater treatment plant subjected to UV-LED (Ultraviolet-Light Emitting Diodes) radiation, emitting UVA (365 and $(405 \mathrm{~nm})$ or UVC $(255$ and $280 \mathrm{~nm})$. The authors indicated that $280 \mathrm{~nm}$ UV-LED appears to be crucial for the success of the disinfection process, with a 4-log reduction being obtained at this wavelength.

The advantages of UV radiation include absence of dangerous co-products or chemicals that could change water composition, in addition to short contact time and inactivation of viruses (Guo et al., 2012; Gibson et al., 2017; Bolyard et al., 2019). After UV radiation treatment, wastewater could be used in agriculture if legal requirements are met and its use does not alter microbial ecosystems in soils (Chevremont et al., 2013). 
The degree of microbial cell inactivation is directly proportional to the UV dose applied. The dose is the amount of UV light emitted by the lamp and is calculated as the radiation intensity multiplied by the duration of exposure, as well as the dose of chemical disinfectants (Gibson et al., 2017; Zewde et al., 2019). Therefore, the use of adequate doses during disinfection is essential for the complete inhibition of microbial growth.

UV radiation intensity decreases when penetrating materials due to its absorption (Artichowicz et al., 2020). Therefore, physicochemical properties of wastewater may affect UV light transmittance, and hence treatment efficiency. In this sense, the efficiency of UV radiation can be affected by water turbidity, suspended solid concentrations, microorganisms, cellular aggregates, leachate, and fluid density, thus requiring higher doses for disinfection process (Hassen et al., 2000; Brahmi et al., 2010; Uslu et al., 2015; Azimi et al., 2017; Bolyard et al., 2019). Of these, turbidity, which is determined by the presence of suspended particles that reflect or absorb radiation, strongly affect UV transmittance and hence disinfection efficiency (Nourmoradi et al., 2012); in addition, colloidal particles tend to favor microbial activity (Burch and Thomas, 1998).

The Center for Agricultural Sciences of the Federal University of São Carlos (CCAUFSCar) manages a Pilot Effluent Treatment Station (ETE), in which a UV sterilizer was used to remove microbial loads; however, the equipment has not performed steadily due to variable wastewater turbidity (Oliveira et al., 2019). Thus, in this study, we assessed at a bench scale the effect of wastewater turbidity and radiation dose on microbial inactivation using a UV sterilizer for effluent treatment.

\section{MATERIAL AND METHODS}

\subsection{Study site}

The study was conducted at the ETE of CCA-UFSCar, located in Araras, São Paulo State, Brazil. The ETE treats up to 2000 liters of wastewater daily from toilets and a university restaurant and has five components (grease box, septic tank, microalgae tank, upflow anaerobic filter, and wetlands) (Figure 1).

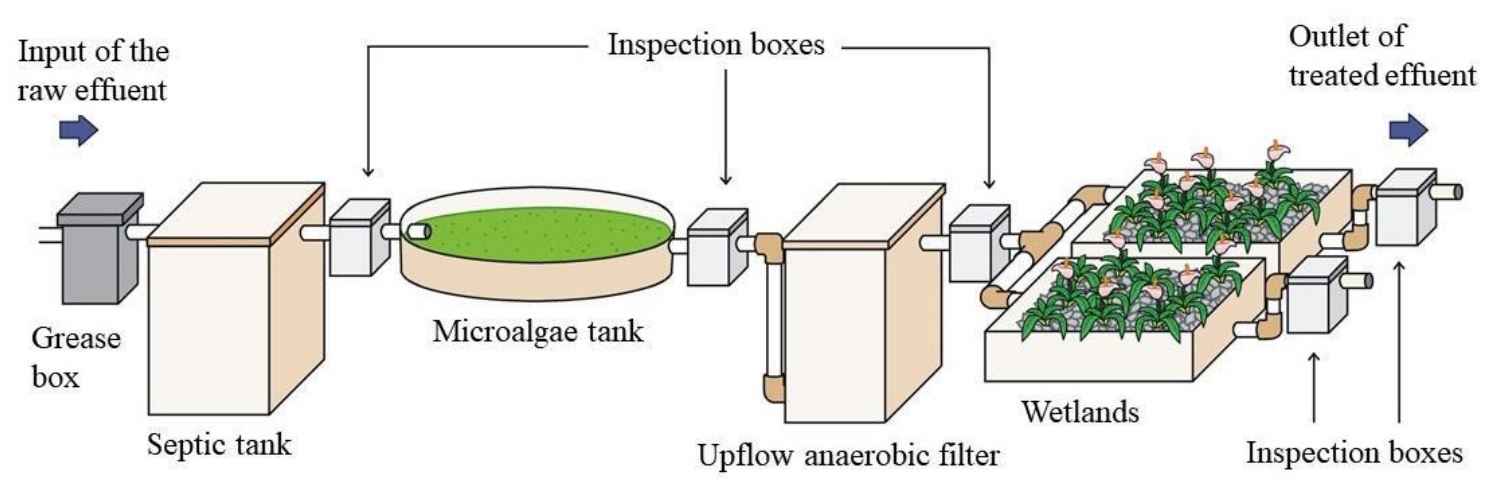

Figure 1. Schematic diagram of the effluent treatment station.

(Source: Souza et al., 2015).

\subsection{Wastewater}

Pretreated effluents were used in the experiments, and sampling sites consisted of inspection boxes located after the wetlands (Figure 1). The effluents were characterized weekly from May to June (Table 1). Sample collection, inspection, preservation, and analyses were performed according to standard methods (APHA et al., 2012).

Turbidity was adjusted to 5, 50, 100, 200, and 300 nephelometric turbidity units (NTU). Average turbidity was $20 \mathrm{NTU}$ and was normalized to 5 NTU by diluting the samples in water. To increase turbidity, a sample from the microalgae tank was centrifuged at $3000 \mathrm{rpm}$ for $5 \mathrm{~min}$ 
and resuspended to obtain a suspension with turbidity higher than $1000 \mathrm{NTU}$. Aliquots were added to diluted samples until the desired turbidity was achieved.

Table 1. Physicochemical and microbiological characteristics of wastewater.

\begin{tabular}{lc}
\hline Variable & Values \\
\hline $\mathrm{pH}$ & $7.50 \pm 0.16$ \\
Turbidity (NTU) & $20.00 \pm 12.16$ \\
$\mathrm{EC}(\mu \mathrm{S} \mathrm{cm}$ & -1 \\
$\mathrm{DO}\left(\mathrm{m} \mathrm{L} \mathrm{L}^{-1}\right)$ & $1030.00 \pm 47.36$ \\
$\mathrm{TOC}\left(\mathrm{mg} \mathrm{L}^{-1}\right)$ & $3.40 \pm 0.90$ \\
$\mathrm{TN}\left(\mathrm{mg} \mathrm{L}^{-1}\right)$ & $26.00 \pm 10.59$ \\
$\mathrm{TP}\left(\mathrm{mg} \mathrm{L}^{-1}\right)$ & $46.00 \pm 6.88$ \\
$\mathrm{TC}\left(\times 10^{6} \mathrm{MPN} 100 \mathrm{~mL}^{-1}\right)$ & $19.00 \pm 6.13$ \\
E. coli $\left(\times 10^{5} \mathrm{MPN} 100 \mathrm{~mL}^{-1}\right)$ & 5.39 \\
\hline
\end{tabular}

EC: electrical conductivity; DO: dissolved oxygen; TOC: total organic carbon; TN: total nitrogen; TP: total phosphorus; TC: total coliforms.

\subsection{Experimental procedure}

Figure 2 shows a schematic of the UV reactor used in the experiments. This reactor was built using a PVC tube and contained a UV germicidal lamp (Philips TUV 75W HO G75 T8 UV $254 \mathrm{~nm}$ ) protected by a quartz cylinder. The average radiation intensity was $0.24 \mathrm{~mW} \mathrm{~cm}^{-2}$. The water depth inside the reactor was $1 \mathrm{~cm}$.

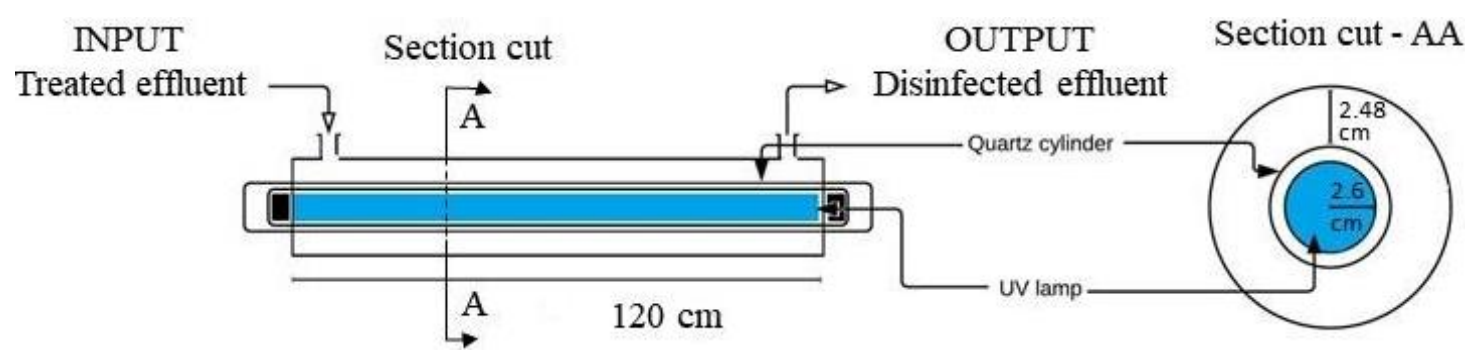

Figure 2. Diagram of the ultraviolet sterilizer.

Sterilization tests were carried out in batches by adding $1500 \mathrm{~mL}$ of a sample with known turbidity. The lamp remained on for $120 \mathrm{~s}$. Samples were collected at 0, 30, 60, 90, and $120 \mathrm{~s}$, and heterotrophic bacteria were counted. At each time point, the radiation dose was calculated by $\mathrm{D}=\mathrm{I} \times \mathrm{t}$, where $D$ is the radiation dose $(\mathrm{mWs} \mathrm{cm}), I$ is the radiation intensity $\left(\mathrm{mW} \mathrm{cm} \mathrm{cm}^{-2}\right)$, and $t$ is the duration of exposure (s) (Zewde et al., 2019). The doses used were 0.0, 7.2, 14.4, 21.6, and $28.8 \mathrm{mWs} \mathrm{cm}^{-2}$.

The collected samples were serially diluted, and $1 \mathrm{~mL}$ aliquots were transferred to $3 \mathrm{M}$ Petrifilm Aqua plates and incubated at $36 \pm 2^{\circ} \mathrm{C}$ for $44 \pm 4$ hours. Bacterial counts were expressed as colony-forming units (CFU) per mL.

A $5 \times 5$ factorial design (five turbidity levels and five radiation doses) was used, totaling 25 treatments. Each treatment was performed in triplicate. The data were submitted to analysis of variance and Tukey's test. The disinfection model was evaluated by the relationship between the logarithmic change in the number of inactivated bacterial cells and the applied dose (Zhou et al., 2016) and followed first-order Chick-Watson kinetics according to Equation 1 (Hijnen et al., 2006): 


$$
\log \left(\frac{N_{0}}{N}\right)=k * D
$$

$$
\begin{aligned}
& \mathrm{N}_{0} \text { - pre-treatment bacterial count, } \mathrm{CFU} \mathrm{mL}^{-1} \text {; } \\
& \mathrm{N} \text { - post-treatment bacterial count, } \mathrm{CFU} \mathrm{mL} \mathrm{m}^{-1} \text {; } \\
& \mathrm{k} \text { - inactivation coefficient, } \mathrm{cm}^{2} \mathrm{mWs}^{-1} \text {; } \\
& \mathrm{D} \text { - radiation dose, } \mathrm{mWs} \mathrm{cm}^{-2} \text {. }
\end{aligned}
$$

\section{RESULTS AND DISCUSSION}

The effect of turbidity was evaluated as a function of transmittance measures of samples. Transmittance is the amount of radiation passing through a sample relative to the emitted radiation. The lower the transmittance, the greater the amount of particles impairing disinfection (Nguyen et al., 2019). Transmittance decreased as turbidity increased (Figure 3).

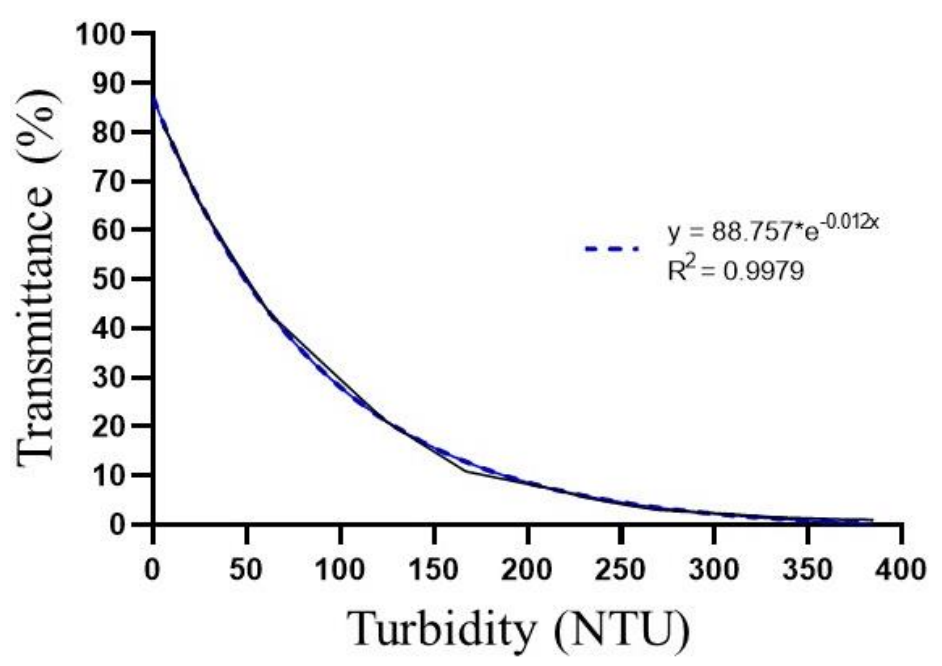

Figure 3. Transmittance profile as a function of turbidity.

The samples with a turbidity of 5, 50, 100, 200, and 300 NTU showed an approximate transmittance of $84 \%, 49 \%, 27 \%, 8 \%$, and $2 \%$, respectively. Figure 2 shows that UV transmittance decreased exponentially with turbidity; therefore, transmittance differences between samples with 5 and 50 NTU were greater than those of samples with 200 and 300 NTU. Similar results were obtained by Nguyen et al. (2019), wherein treatments that reduced effluent turbidity increased UV transmittance.

The dose of radiation absorbed by microorganisms is hard to be measured and varies with emitted light and period of exposure (Gayan et al., 2011). Given that decimal reduction times are longer (lower microbial inactivation) for heterotrophic bacteria in treated effluents, it is possible to estimate the duration of exposure for samples with turbidity levels of up to 300 NTU. Failly (1994) recommended a minimum dose of $30 \mathrm{mWs} \mathrm{cm}{ }^{-2}$ for wastewater, although the dose depends on the type of installation and the physicochemical characteristics of the effluent (Hassen et al., 2000).

Turbidity may increase or transmittance decrease with the addition of several compounds (Bolyard et al., 2019; Azimi et al., 2012; Carré et al., 2018). Depending on the material used, the efficiency of UV disinfection in inactivating microorganisms varies (Farrell et al., 2018). For instance, ultrasound treatment did not decrease effluent turbidity but increased the efficiency of UV disinfection (Zhou et al., 2016).

Microbial aggregates are formed during biological or secondary treatments through 
incorporation or adsorption of microorganisms to suspended particles. These aggregates help protect microorganisms against UV radiation and decrease disinfection efficiency (Azimi et al., 2017). Therefore, the use of a microalgae suspension to increase turbidity may have decreased the efficiency of disinfection by decreasing transmittance and promoting the formation of bacterial aggregates.

To evaluate the effect of turbidity and radiation dose on disinfection, doses of $0,7.2,14.4$, 21.6, and $28.8 \mathrm{mWs} \mathrm{cm}^{-2}$ were applied for $30,60,90$, and $120 \mathrm{~s}$, respectively, for effluents with a turbidity of 5, 50,100, 200, and 300 NTU. The results showed that the samples with a turbidity of 5 and 50 NTU presented the highest levels of disinfection. Inactivation was higher than $99.97 \%$ for all turbidity levels at a dose of $28.8 \mathrm{mWs} \mathrm{cm}^{-2}$. These results agree with those of USEPA (2006), which indicated that the dose required for killing $99.99 \%$ of coliforms in wastewater was at least $20 \mathrm{mWs} \mathrm{cm}^{-2}$.

The analysis of variance showed significant differences due to interaction between factors $(\mathrm{p}<0.05)$. Therefore, the efficiency of disinfection was analyzed according to turbidity levels and radiation doses (Table 2). All turbidity levels tested showed significant disinfection efficiency differences among radiation doses. The analysis also proved that $95 \%$ of the variation was caused by radiation doses. Thus, dose variations had a greater impact on bacterial inactivation than did turbidity changes, which agrees with a previous study (Farrell et al., 2018).

Table 2. Log-cycle reduction for the inactivation of heterotrophic bacteria as a function of the duration of exposure, radiation dose, and sample turbidity.

\begin{tabular}{|c|c|c|c|c|c|c|}
\hline \multirow{3}{*}{$\begin{array}{l}\text { Duration of } \\
\text { exposure (s) }\end{array}$} & \multirow{3}{*}{$\begin{array}{l}\text { Radiation dose } \\
\left(\mathrm{mWs} \mathrm{cm}{ }^{-2}\right)\end{array}$} & \multicolumn{5}{|c|}{ Turbidity (NTU) } \\
\hline & & 5 & 50 & 100 & 200 & 300 \\
\hline & & \multicolumn{5}{|c|}{ Log-cycle reduction } \\
\hline $0 \mathrm{~s}$ & 0 & $0.00 \mathrm{Aa}$ & $0.00 \mathrm{Aa}$ & $0.00 \mathrm{Aa}$ & $0.00 \mathrm{Aa}$ & $0.00 \mathrm{Aa}$ \\
\hline $30 \mathrm{~s}$ & 7.2 & $1.56 \mathrm{Ba}$ & 1.40 Bab & $1.18 \mathrm{Bbc}$ & $0.99 \mathrm{Bcd}$ & $0.84 \mathrm{Bd}$ \\
\hline $60 \mathrm{~s}$ & 14.4 & $2.62 \mathrm{Ca}$ & $2.64 \mathrm{Ca}$ & $2.26 \mathrm{Cb}$ & $1.96 \mathrm{Cc}$ & $1.88 \mathrm{Cc}$ \\
\hline $90 \mathrm{~s}$ & 21.6 & $3.59 \mathrm{Da}$ & $3.74 \mathrm{Da}$ & $3.29 \mathrm{Db}$ & $2.97 \mathrm{Dc}$ & $2.81 \mathrm{Dc}$ \\
\hline $120 \mathrm{~s}$ & 28.8 & $5.11 \mathrm{Ea}$ & $4.88 \mathrm{Ea}$ & $4.59 \mathrm{~Eb}$ & $4.32 \mathrm{Ec}$ & $3.58 \mathrm{Ed}$ \\
\hline
\end{tabular}

Means with the same uppercase letters in each column and the same lowercase letters in each line were not significantly different from each other by the Tukey's test at a significance level of 5\%.

At each radiation dose, there were no significant differences in bacterial elimination between samples with 5 and 50 NTU. Besides, at the exposure times of 30, 60, and $90 \mathrm{~s}$, there were no significant differences in bacterial elimination between samples with 200 and 300 NTU. However, above 50 NTU, higher turbidity levels decreased microbial inactivation significantly. Thus, despite applying the same doses, turbidity had a negative effect on UV disinfection, and as dose increases, such differences become greater.

The inactivation of heterotrophic microorganisms using a contact reactor was greater than that obtained by Chhetri et al. (2018), who used similar doses in a reactor without direct contact, indicating that the type of reactor strongly affected disinfection efficiency. Sanctis et al. (2016) found that total coliforms in domestic wastewater decreased by $2.8 \mathrm{logs}$ using a dose of $40 \mathrm{mWs}$ $\mathrm{cm}^{-2}$. In our study, heterotrophic bacteria counts were reduced by $3.0 \operatorname{logs}$ at a dose of $20 \mathrm{mWs}$ $\mathrm{cm}^{-2}$ and by $5 \operatorname{logs}$ at a dose of $28.8 \mathrm{mWs} \mathrm{cm}^{-2}$ in samples with a turbidity of 5 NTU. Nguyen et al. (2019) reported that the total count of E. coli was reduced by 5 logs in domestic wastewater pretreated with a UV dose of $69.4 \mathrm{mWs} \mathrm{cm}^{-2}$ in samples with an initial turbidity of 4 NTU.

Our results were similar to those obtained by Guo et al. (2011), in which counts of E. coli 
and fecal coliforms were reduced by 5 logs, and total counts of $B$. subtilis were reduced by 4 logs using $40 \mathrm{mWs} \mathrm{cm}^{-2}$. However, other studies found that killing efficiency was higher using UV doses lower than $40 \mathrm{mWs} \mathrm{cm}^{-2}$ (Lazarova et al., 1999; Beck et al., 2016; Nyangaresi et al. (2018). Silva et al. (2020) obtained similar results with much lower irradiance intensity using $280 \mathrm{~nm}$ UV-LED $(0.019 \mathrm{~mW} \mathrm{~cm} \mathrm{-} \mathrm{2)} \mathrm{with} \mathrm{a} 4 \log$ reduction of $15 \mathrm{~min}$ E. coli. This wavelength range from 280 to $200 \mathrm{~nm}$, called UVC and used in our experiments, appears to cause more effective and irreversible damage to DNA. Therefore, it is also important to consider this aspect combined with the physicochemical characteristics of the effluent and irradiance intensity.

Previous studies demonstrated that increases in turbidity have a negative effect on UV disinfection effectiveness. Nourmoradi et al. (2012) used a UV reactor like that used in our study and reported that an increase in turbidity from 1 to 5 NTU reduced inactivation effectiveness by $0.2-0.5 \mathrm{log}$. Wu and Doan (2005) also reported a decrease in inactivation efficiency as turbidity increased from 1 to 5 NTU, and Gullian et al. (2012) observed that microbial inactivation decreased as turbidity was raised from 9 to 28 NTU. Likewise, Zhou et al. (2016) reported that increases in turbidity and UV absorbance reduce efficiency of disinfection.

In the above studies, small changes in turbidity had great impacts on disinfection efficiency. However, in ours, only major changes impacted the treatment, even though we expected greater differences after analyzing Figure 3. This discrepancy might have been due to the composition of microalgae used to increase sample turbidity. The phosphate concentration in microalgae is high, and these microorganisms absorb phosphorus from the medium during wastewater treatment (Sajjadi et al., 2018).

Azimi et al. (2014a) reported that floc-forming during biological treatment with polyphosphates would enhance UV-radiation disinfection by acting as photoactive agents and producing oxidative hydroxyl radicals. In addition, effluents with low phosphorus concentrations are more resistant to UV disinfection than effluents with higher phosphorus levels (Azimi et al., 2014b). Thus, the presence of microalgae biomass may have benefited disinfection since, despite the increase in turbidity and reduction in transmittance, its efficiency has not dropped dramatically.

The $\mathrm{k}$ value indicates the sensitivity of microorganisms to UV radiation (Hijnen et al., 2006) and was calculated using Equation 1 (Figure 4). The k values (slopes) varied from 0.1266 to $0.1759 \mathrm{~cm}^{2}(\mathrm{mWs})^{-1}$.

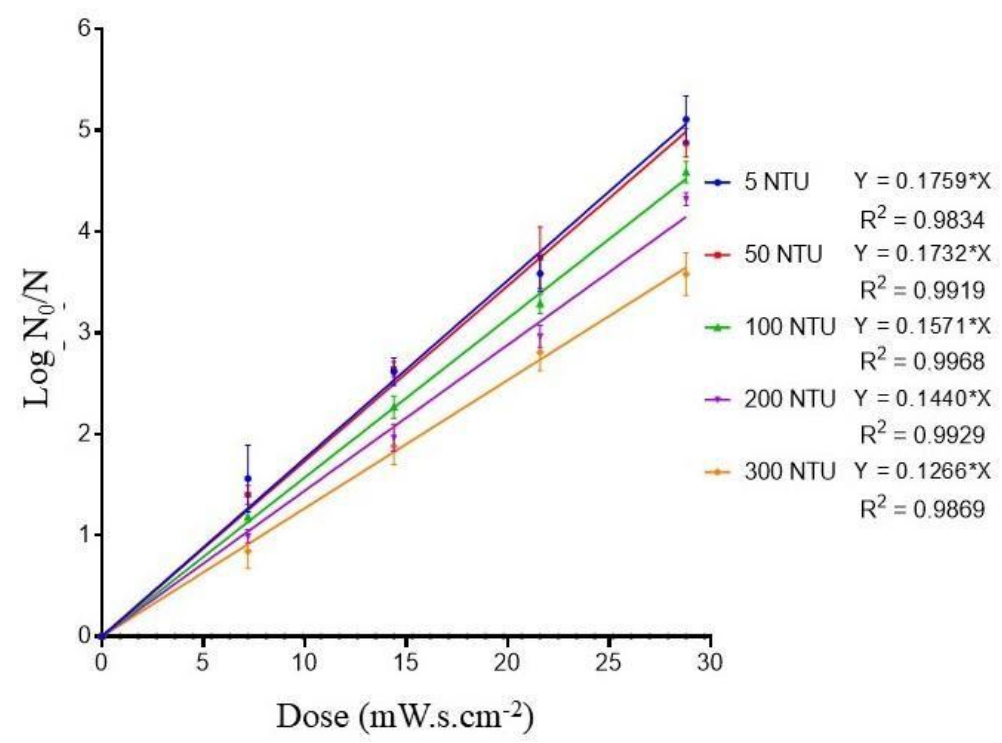

Figure 4. Microbial inactivation profile $\left(\log \mathrm{N}_{0} / \mathrm{N}\right)$ for each turbidity level as a function of UV dose. 
The $\mathrm{k}$ values vary depending on the microorganism, UV radiation system, and the type and physicochemical characteristics of wastewater. The obtained $\mathrm{K}$ values agree with the literature. Zhou et al. (2016) reported that $\mathrm{k}$ values for the UV inactivation of E. coli in municipal wastewater varied between 0.1027 and $0.1887 \mathrm{~cm}^{2} \mathrm{mWs}^{-1}$, and Oguma et al. (2016) found that the $\mathrm{k}$ value for the inactivation of $E$. coli in synthetic media was $0.157 \mathrm{~cm}^{2} \mathrm{~mJ}^{-1}$. In contrast, Beck et al. (2016) reported that the k value for killing E. coli using a low-pressure UV lamp was $0.31 \mathrm{~cm}^{2} \mathrm{mWs}^{-1}$.

Torres-Palma et al. (2017) observed that pretreatment increased the efficiency of UV disinfection, and the $\mathrm{k}$ value for inactivating fecal coliforms in secondary effluents pretreated with hexanol and ultrasound was $0.3 \mathrm{~cm}^{2} \mathrm{mWs}^{-1}$.

The results indicate that the $\mathrm{k}$ values estimated here can be extrapolated to disinfection of effluents at the ETE of CCA/UFSCar, with turbidity values below 300 NTU. This is because thermotolerant coliforms are classified as heterotrophic bacteria.

According to CONAMA Resolution 357/05 (CONAMA, 2005), the maximum concentration of thermotolerant coliforms estimated by the technique of the most probable number (MPN) of CFU per $100 \mathrm{~mL}$ in reuse water should be 100 (Classes 1 and 2) and 2000 (Class 3). The MPN of E. coli in the effluents was $3.53 \times 10^{5}$ (Table 1).

A disinfection efficiency of $99.999 \%$ ( 5 log reduction) would be necessary to obtain a bacterial count of fewer than 2000 coliforms. The time required to achieve this goal can be calculated from the $\mathrm{k}$ value at a given turbidity, with the number of $\log$ cycles required being obtained by the product $\mathrm{k}$ versus dose of UV radiation (D).

\section{CONCLUSION}

Our results indicated that turbidity in wastewater samples influence bacterial inactivation by ultraviolet light. Inactivation coefficients between 0.1266 and $0.1759 \mathrm{~cm}^{2}\left(\mathrm{mWs}^{-1}\right)$ reduce heterotrophic bacteria counts by more than $99.999 \%$, i.e., more than 5 log cycles. This efficiency could be improved by increasing the time of exposure to ultraviolet.

\section{ACKNOWLEDGEMENTS}

The authors are grateful to CAPES, FAPESP - 2013/14893-7 and CNPq.

\section{REFERENCES}

APHA; AWWA; WEF. Standard Methods for the examination of water and wastewater. 22nd ed. Washington, 2012. 1496 p.

ARTICHOWICZ, W.; LUCZKIEWICZ, A.; SAWICKI, J. M. Analysis of the Radiation Dose in UV-Disinfection Flow Reactors. Water, Basel, v. 12, n. 1, p. 231, 2020. https://doi.org/10.3390/w12010231

AZIMI, Y.; ALLEN, D. G.; FARNOOD, R. R. Kinetics of UV inactivation of wastewater bioflocs. Water Research, v. 46, n. 12, p. 3827-3836, 2012. https://doi.org/10.1016/j.watres.2012.04.019

AZIMI, Y.; ALLEN, D. G.; FARNOOD, R. R. Enhancing disinfection by advanced oxidation under UV irradiation in polyphosphate-containing wastewater flocs. Water Research, Amsterdam, v. 54, p. 179-187, 2014a. https://doi.org/10.1016/j.watres.2014.01.011 
AZIMI, Y.; ALLEN, D. G.; SETO, P.; FARNOOD, R. R. Effect of Activated Sludge Retention Time, Operating Temperature, and Influent Phosphorus Deficiency on Floc Physicochemical Characteristics and UV Disinfection. Industrial \& Engineering Chemistry Research, v. 53, v. 31, p. 12485-12493, 2014b. https://doi.org/10.1021/ie5012068

AZIMI, Y.; LIU, Y.; TAN, T. C.; ALLEN, D. C.; FARNOOD, R. R. The tail of two models: Impact of circularity and biomass non-homogeneity on UV disinfection of wastewater flocs. Water Research, Amsterdam, v. 126, p. 70-78, 2017. https://doi.org/10.1016/j.watres.2017.09.011

BECK, S. E.; RODRIGUEZ, R. A.; HAWKINS, M. A.; HARGY, T. M.; LARASON, T. C.; LINDEN, K. G. Comparison of UV-Induced Inactivation and RNA Damage in MS2 Phage across the Germicidal UV Spectrum. Applied and Environmental Microbiology, v. 82, n. 5, p. 1468-1474, 2016. https://doi.org/10.1128/AEM.02773-15

BOLYARD, S. C.; MOTLAGH, A. M.; LOZINSKI, D.; REINHART, D. R. Impact of organic matter from leachate discharge to wastewater treatment plants on effluent quality and UV $\begin{array}{llllll}\text { disinfection. Waste Management, } & \text { v. 88, p. 257-267, }\end{array}$ https://doi.org/10.1016/j.wasman.2019.03.036

BRAHMI, M.; BELHADI, N. H.; HAMDI, H.; HASSEN, A. Modeling of secondary treated wastewater disinfection by UV irradiation: Effects of suspended solids content. Journal of Environmental Sciences, v. 22, p. 1218-1224, 2010. http://dx.doi.org/10.1016/S10010742(09)60241-2

BURCH, J.; THOMAS, K. Water disinfection for developing countries and potential for solar thermal pasteurization. Solar Energy, v. 64, p. 87-97, 1998. http://dx.doi.org/10.1016/S0038-092X(98)00036-X

CARRÉ, E.; PÉROT, J.; JAUZEIN, V.; LOPEZ-FERBER, M. Impact of suspended particles on UV disinfection of activated-sludge effluent with the aim of reclamation. Journal of $\begin{array}{lllllll}\text { Water Process } & \text { Engineering, } & \text { v. } & 22, & \text { p. } & 87-93,\end{array}$ https://doi.org/10.1016/j.jwpe.2018.01.016

CHAI, Q.; HU, A.; QIAN, Y.; AO, X.; LIU, W.; YANG, H.; XIE, Y. F. A comparison of genotoxicity change in reclaimed wastewater from different disinfection processes. $\begin{array}{lllll}\text { Chemosphere, } & \text { v. } & 191, & \text { p. } & 335-341,\end{array}$ https://doi.org/10.1016/j.chemosphere.2017.10.024

CHEVREMONT, A. C.; BOUDENNE, J. L.; COULOMB, B.; FARNET, A. M. Impact of watering with UV-LED-treated wastewater on microbial and physico-chemical parameters of soil. Water Research, v. 47, n. 6, p. 1971-1982, 2013. https://doi.org/10.1016/j.watres.2013.01.006

CHHETRI, R. K.; KLUPSCH, E.; ANDERSEN, H. R.; JENSEN, P. E. Treatment of Arctic wastewater by chemical coagulation, UV and peracetic acid disinfection. Environmental Science and Pollution Research, v. 25, p. 32851-32859, 2018. https://doi.org/10.1007/s11356-017-8585-5

COLliVignARElli, M. C.; ABBÀ, A.; BENIGNA, I.; SORLINI, S.; TORRETTA, V. Overview of the main disinfection processes for wastewater and drinking water treatment plants. Sustainability, v. 10, n. 1, p. 86, 2018. https://doi.org/10.3390/su10010086 
CONAMA (Brasil). Resolução n 357 de 17 de março de 2005. Dispõe sobre a classificação dos corpos de água e diretrizes ambientais para o seu enquadramento, bem como estabelece as condições e padrões de lançamento de efluentes, e dá outras providências. Diário Oficial [da] União: seção 1, Brasília, DF, n. 053, p. 58-63, 18 mar. 2005.

FARRELL, C.; HASSARD, F.; JEFFERSON, B.; LEZIART, T.; NOCKER, A.; JARVIS, P. Turbidity composition and the relationship with microbial attachment and UV inactivation efficacy. Science of the Total Environment, v. 624, p. 638-647, 2018. https://doi.org/10.1016/j.scitotenv.2017.12.173

FAILLY, J. Desinfection des eaux usées par rayonnement ultraviolet. L'eau, l'industrie, les Nuisances, n. 176, p. 58-60, 1994.

GAYAN, E.; MONFORT, S.; ÁLVAREZ, I.; CONDÓN, S. UV-C inactivation of Escherichia coli at different temperatures. Innovative Food Science and Emerging Technologies, Amsterdam, v. 12, n. 4, p. 351-341, 2011. http://dx.doi.org/10.1016/j.ifset.2011.07.008

GIBSON, J.; DRAKE, J.; KARNEY, B. UV Disinfection of wastewater and combined sewer overflows. In: AHMAD, S. (eds.). Ultraviolet Light in Human Health, Diseases and Environment. Advances in Experimental Medicine and Biology. New York: Springer, 2017. https://doi.org/10.1007/978-3-319-56017-5_22

GULLIAN, M.; ESPINOSA-FALLER, F. J.; NÚÑEZ, A.; LÓPEZ-BARAHONA, N. Effect of turbidity on the ultraviolet disinfection performance in recirculating aquaculture systems with low water exchange. Aquaculture Research, v. 43, n. 4, p. 595-606, 2012. https://doi.org/10.1111/j.1365-2109.2011.02866.x

GUO, M.; HU, H.; LIU, W. Preliminary investigation on safety of post-UV disinfection of wastewater: bio-stability in laboratory-scale simulated reuse water pipelines. Desalination, v. 239, p. 22-28, 2009. http://dx.doi.org/10.1016/j.desal.2008.03.003

GUO, M.; HUANG, J.; HU, H.; LIU, W. Growth and repair potential of three species of bacteria in reclaimed wastewater after UV disinfection. Biomedical and Environmental Sciences, v. 24, n. 4, p. 400-407, 2011. https://doi.org/10.3967/0895-3988.2011.04.011

GUO, M.; HUANG, J.; HU, H.; LIU, W.; YANG, J. UV inactivation and characteristics after photoreactivation of Escherichia coli with plasmid: Health safety concern about UV disinfection. Water Research, v. 46, n. 13, p. 4031-4036, 2012. http://dx.doi.org/10.1016/j.watres.2012.05.005

HASSEN, A.; MAHROUK, M.; OUZARI, H.; CHERIF, M.; BOUDABOUS, A.; DAMELINCOURT, J. J. UV disinfection of treated wastewater in a large-scale pilot plant and inactivation of selected bacteria in a laboratory UV device. Bioresource Technology, v. 7, n. 2, p. 141-150, 2000. http://dx.doi.org/10.1016/S0960-8524(99)00179-0

HIJNEN, W. A. M.; BEERENDORK, E. F.; MEDEMA, G. J. Inactivation credit of UV radiation for viruses, bacteria and protozoan (oo)cysts in water: a review. Water Research, v. 40, n. 1, p. 3-22, 2006. https://doi.org/10.1016/j.watres.2005.10.030

LAZAROVA, V.; SAVOYE, P.; JANEX, M. L.; BLATCHLEY, E. R.; POMMEPUY, M. Advanced wastewater disinfection technologies: state of the art and perspectives. Water Science \& Technology, v. 40, n. 4-5, p. 203-213, 1999. https://doi.org/10.1016/S02731223(99)00502-8 
MASSCHELEIN, J.; DEBACKER, S.; CHEBAK, S. Etude sur modèle de la désinfection de l'eau par rayonnements ultraviolets. Reveu des Sciences de l'eau, v. 2, n. 1, p. 29-41, 1989. https://doi.org/10.7202/705022ar

NGUYEN, D. D.; JONES, N. C.; HOFFMANN, S. V.; SPANGET-LARSEN, J. UV synchrotron radiation linear dichroism spectroscopy of the anti-psoriatic drug anthralin. Journal for Physical Chemistry, v. 1, p. e5, 2019. https://doi.org/10.7717/peerjpchem.5

NOURMORADI, H.; NIKAEEN, M.; STENSVOLD, C. R.; MIRHENDI, H. Ultraviolet irradiation: An effective inactivation method of Aspergillus spp. in water for the control of waterborne nosocomial Aspergillosis. Water Research, v. 46, n. 18, p. 5935-5940, 2012. https://doi.org/10.1016/j.watres.2012.08.015

NYANGARESI, P.; QIN, Y.; CHEN, G.; ZHANG, B.; LU, Y.; SHEN, L. Effects of single and combined UV-LEDs on inactivation and subsequent reactivation of $E$. coli in water disinfection. Water Research, v. 147, p. 331-341, 2018. https://doi.org/10.1016/j.watres.2018.10.014

OGUMA, K.; RATTANAKUL, S.; BOLTON, J. R. Application of UV light-emitting diodes to adenovirus in water. Journal of Environmental Engineering, v. 142, n. 3, p. 04015082, 2016. https://doi.org/10.1061/(ASCE)EE.1943-7870.0001061

OLIVEIRA, A. A. S.; BASTOS, R. G.; SOUZA, C. F. Adaptation of domestic effluent for agricultural reuse by biological, physical treatment and disinfection by ultraviolet radiation. Revista Ambiente \& Água, v. 14, n. 2, p. 1-10, 2019. https://doi.org/10.4136/ambi-agua.2292

SAJJADI, B.; CHEN, W. Y.; RAMAN, A. A. A.; IBRAHIM, S. Microalgae lipid and biomass for biofuel production: A comprehensive review on lipid enhancement strategies and their effects on fatty acid composition. Renewable and Sustainable Energy Reviews, v. 97, p. 200-232, 2018. https://doi.org/10.1016/j.rser.2018.07.050

SANCTIS, M.; MORO, G.; LEVANTESI, C.; LUPRANO, M. L.; IACONI, C. Integration of an innovative biological treatment with physical or chemical disinfection for wastewater reuse. Science of the Total Environment, v. 543, p. 206-213, 2016. https://doi.org/10.1016/j.scitotenv.2015.11.006

SILVA, N. B.; LEONEL, L. P.; TONETTI, A. L. UV-LED for safe effluent reuse in agriculture. Water, Air, \& Soil Pollution, v. 231, 343, 2020. https://doi.org/10.1007/s11270-02004742-4

SOUZA, C. F.; BASTOS, R. G.; GOMES, M. P. M.; PULSCHEN, A. A. Efficiency of domestic wastewater treatment plant for agricultural reuse. Revista Ambiente \& Água, v. 10, n. 3, p. 587-597, 2015. https://doi.org/10.4136/ambi-agua.1549

TORRES-PALMA, R.; GIBSON, J.; DROPPO, I.; SETO, P.; FARNOOD, R. Surfactantassisted sono-breakage of wastewater particles for improved UV disinfection. Water, Air, \& Soil Pollution, v. 228, 106, 2017. https://doi.org/10.1007/s11270-017-3283-y

USEPA. Ultraviolet disinfection guidance manual for the final long term 2 enhanced surface water treatment rule, EPA, 815-R-06-007. Washington, 2006. https://nepis.epa.gov/Exe/ZyPURL.cgi?Dockey=600006T3.TXT 
USLU, G.; DEMIRCI, A.; REGAN, J. Efficacy of pulsed UV-Light treatment on wastewater effluent disinfection and suspended solid reduction. Journal Environmental Engineering, v. 141, n. 6, p. 22-28, 2015. http://dx.doi.org/10.1061/(ASCE)EE.19437870.0000912

WU, J.; DOAN, H. Disinfection of recycled red-meat-processing wastewater by ozone. Journal of Chemical Technology and Biotechnology, v. 80, n. 7, p. 828-833, 2005. https://doi.org/10.1002/jctb.1324

ZEWDE, A. A.; ZHANG, L.; LI, Z.; ODEY, E. A. A review of the application of sonophotocatalytic process based on advanced oxidation process for degrading organic dye. Reviews on Environmental Health, v. 34, n. 4, p. 365-375, 2019. https://doi.org/10.1515/reveh-2019-0024

ZHOU, X.; LI, Z.; LAN, J.; YAN, Y.; ZHU, N. Kinetics of inactivation and photoreactivation of Escherichia coli using ultrasound-enhanced UV-C light-emitting diodes disinfection. $\begin{array}{llllll}\text { Ultrasonics Sonochemistry, v. 35, p. 471-477, } 2016 . & \end{array}$ https://doi.org/10.1016/j.ultsonch.2016.10.028 